\title{
Estimation of Rainwater Quality Using GPS-derived Atmospheric Propagation Delay and Meteorological Data
}

\author{
Prawit Uang-Aree ${ }^{1,3}$, Sununtha Kingpaiboon ${ }^{2 *}$, Kulyakorn Khuanmar ${ }^{1}$ \\ ${ }^{1}$ Department of Environmental Engineering, Faculty of Engineering, Khon Kaen University, Khon Kaen, Thailand \\ ${ }^{2}$ Department of Agricultural Engineering, Faculty of Engineering, Khon Kaen University, Khon Kaen, Thailand \\ ${ }^{3}$ Faculty of Science and Technology, Sakon Nakhon Rajabhat University, Sakon Nakhon, Thailand
}

Received: 29 November 2015

Accepted: 6 February 2016

\begin{abstract}
We investigated GPS-derived atmospheric propagation delays and meteorological data for estimating rainwater quality by creating a regression model using the combinatorial group method of the datahandling algorithm (COMBI GMDH). The dependent variable was the daily wet deposition, while the independent variables were zenith hydrostatic delay, zenith wet delay, daily rainfall, and daily average wind speed. The model had a coefficient of determination $\left(R^{2}\right)$ of 0.70 and a correlation coefficient of 0.84 . The mean absolute error (MAE) was 30.20, $\mu \mathrm{mol} / \mathrm{m}^{2}$-day and the root mean square error (RMSE) was $40.94 \mu \mathrm{mol} / \mathrm{m}^{2}$-day. Accuracy testing to validate the model revealed an $R^{2}$ of 0.95 with a correlation coefficient of 0.98 . The MAE was $12.14 \mu \mathrm{mol} / \mathrm{m}^{2}$-day and the RMSE $15.35 \mu \mathrm{mol} / \mathrm{m}^{2}$-day. Rainwater quality could be estimated using GPS-derived atmospheric propagation delay (APD) and meteorological data.
\end{abstract}

Keywords: acid rain, pollution, rain water monitoring, COMBI GMDH

\section{Introduction}

Industrial development has released pollutants into the environment everywhere on the globe that adversely affect soil, water, and air. Changes that occurred through contaminants in both the local ecosystem and the biosphere have contributed to environmental hazards such as pollution and global climate change [1]. Since the industrial revolution 200 years ago, the human collective has resulted in waste gas emissions from fossil fuel combustion (i.e., from coal, oil, and natural gas). This has released nitrogen oxides (NOx), sulfur oxides (SOx)

*e-mail: sununtha@kku.ac.th and carbon dioxide $\left(\mathrm{CO}_{2}\right)$ into the environment [2]. The emission of $\mathrm{CO}_{2}$ and other gases (viz., $\mathrm{CH}_{4}, \mathrm{~N}_{2} \mathrm{O}, \mathrm{HFCs}$, PFCs, $\mathrm{SF}_{6}$ ) have caused a greenhouse effect, and both NOx and SOx are also detrimental to health - these gases cause acid rain, which destroys the freshwater ecosystem and diminishes its recreational value [3]. Fossil fuel energy consumption is a major factor affecting our environment.

Rainwater is one of the most important natural resources [4], providing moisture to nourish humans, animals, and plants; however, with increasing air pollution from fossil fuel combustion, rainwater is contaminated and acidified by sulfuric and nitric acid [4]. The forests and watersheds are damaged [5] and nutrients in the soil eroded [6]. This has an adverse effect on livelihoods, even 
on residential buildings and historic sites [7]. As rainwater quality declines, it will no longer be fit for consumption or agriculture $[8,9]$.

Responsible environmental management entails the monitoring, analysis and control of acid rain, which require expertise, time, and money. There is a low pollution concentration in rain, so in order to obtain accurate and meaningful results a laboratory with advanced equipment is necessary; particularly to determine the ionic charge in the water using ion chromatography techniques. The current research proposes (a) a GPS-derived atmospheric propagation delay plus meteorological data for estimating wet deposition and (b) a combinatorial group method for data handling (COMBI GMDH) through computational modeling.

\section{Materials and Methods}

Our research comprised five steps: 1) rainwater sampling, 2) rainwater quality and wet deposition analysis, 3) GPS data recording, 4) analyzing the GPS-derived atmospheric propagation delay, and 5) regression analysis of the COMBI GMDH.

\section{Rainwater Collection}

Rainwater was collected (in a wet-only $200 \mathrm{~mm}$ diameter collector) every $24 \mathrm{~h}$ between 10 September 2013 and 9 September 2014 at Khon Kaen University (16 $\left.28^{\prime} 19.8^{\prime \prime} \mathrm{N}, 102^{\circ} 49^{\prime} 30.7^{\prime \prime} \mathrm{E}\right)$. Samples were stored in polyethylene bottles and stored at $4^{\circ} \mathrm{C}$. To prevent contamination, the sample collector was cleaned with deionized water and new bottles were used every day.

\section{Analyzing Rainwater Quality and Wet Deposition}

Each rainwater sample was weighed and the quality analyzed as per standard methods [10]. $\mathrm{pH}$ was measured using an electrical approach (part 4500- $\mathrm{H}^{+}$B.), and the quantities of $\mathrm{Ca}^{2+}, \mathrm{Mg}^{2+}, \mathrm{Na}^{+}, \mathrm{K}^{+}$, and $\mathrm{NH}^{4+}$ determined by ion chromatography (part 4110 C.), using a Dionex ${ }^{\mathrm{TM}}$ Ion Chromatography, Model DX-100. A Dionex ${ }^{\mathrm{TM}}$ Ion Chromatograph Model ICS-1000 analyzed the anions (viz., $\mathrm{SO}_{4}^{2-}, \mathrm{NO}^{3-}, \mathrm{Cl}^{-}, \mathrm{PO}_{4}^{3-}, \mathrm{HCOO}^{-}$, and $\mathrm{CH}_{3} \mathrm{COO}^{-}$).

Wet deposition analysis (acidic rain) was calculated from the wet deposition flux density; it took into account the concentration of the pollutants in the precipitation, precipitation volume, and the catchment size of the collector (equation below):

$$
\mathrm{F}=\frac{\mathrm{C} * \mathrm{~V}}{\mathrm{~A}}
$$

...where ' $\mathrm{F}$ ' is the daily wet deposition flux $\left(\mu \mathrm{mol} / \mathrm{m}^{2}\right.$ day), ' $C$ ' the concentration of the pollutants $(\mu \mathrm{mol} / \mathrm{L})$, ' $\mathrm{V}$ ' the daily precipitation volume (L/day), and ' $\mathrm{A}$ ' the catchment size of the rainwater collector $\left(\mathrm{m}^{2}\right)$. The daily precipitation volume was calculated from:

$$
\mathrm{V}=\frac{\mathrm{m}}{\rho_{\mathrm{w}}}
$$

...where ' $\mathrm{m}$ ' is the precipitation mass $(\mathrm{g})$ and ' $\rho_{\mathrm{w}}$ ' the water density with a value of $999.97 \mathrm{~g} / \mathrm{L}$.

\section{Recording GPS Data}

GPS data were recorded between 10 September 2013 and 9 September 2014 with a Trimble dual frequency GPS ground receiver, Model 4000SSi installed at Khon Kaen University. The geographical location was $16^{\circ} 28^{\prime} 22^{\prime} \mathrm{N}$, $102^{\circ} 49^{\prime} 22^{\prime \prime} E$ (Fig. 1). GPS data were recorded every 30 seconds. The binary data from the GPS data were decoded and recorded in receiver independent exchange format or RINEX, using COM2RNX software, then transmitted to an IBM file-server every $24 \mathrm{~h}$.

\section{Analyzing the GPS-Derived Atmospheric Propagation Delay}

The recorded GPS data were analyzed by postprocessing to estimate the GPS-derived atmospheric propagation delay using the double difference method (DD)-GAMIT version 10.5, with software C-shell scripts developed by the Massachusetts Institute of Technology [11].

The value of the GPS-derived atmospheric propagation delay estimated from the GAMIT software was the delay in the GPS signal transmission through the atmosphere, transmitted with a dual-frequency microwave signal from the GPS satellite to the ground base. This delay is known as zenith total delay (ZTD) or zenith path delay (ZD), which can vary due to refraction of gas, water vapor, and other particles in the atmosphere [12]. The formula is:

$$
Z T D=\int_{\text {ground }}^{T O A} N(z) D Z
$$

...where ' $\mathrm{N}$ ' is total refraction, ' $\mathrm{z}$ ' the geometric height, and 'TOA' the top limit of the atmosphere. Considering the gas elements in the atmosphere, ZTD can be divided into two sub-delays: 1) the zenith hydrostatic delay (ZHD) - refraction of dry gas in the atmosphere - and 2) the zenith wet delay (ZWD) - refraction through water vapor in the atmosphere [13],

$$
\mathrm{ZTD}=\mathrm{ZHD}+\mathrm{ZWD}
$$

The ZHD of the GPS was the major element of ZTD with a value of $80-90 \%$, depending on the season, region, and location of the base station. The value was estimated from the surface pressure, latitude, and height of the station, as defined by: 


$$
\mathrm{ZHD}=(2.2779 \pm 0.0024) \frac{\mathrm{P}_{\mathrm{S}}}{f(\phi, \mathrm{H})}
$$

...where ' $\mathrm{P}_{\mathrm{s}}$ ' is the surface pressure (mbar), ' $\phi$ ' the latitude of the base station, and ' $\mathrm{H}$ ' the ellipsoid height of the ground station $(\mathrm{km})$. The function $f(\phi, \mathrm{H})$ was calculated from Equation 6.

$f(\phi, \mathrm{H})=f(\phi, \mathrm{H})=(1-0.00266 \cos 2 \phi-0.00028 H)$
When ZHD is calculated, ZWD is found by deducting the ZHD value from ZTD, as estimated using the GAMIT software.

\section{Regression Analysis by Applying COMBI GMDH}

We analyzed the relationship between GPS-derived atmospheric propagation delay and meteorological data estimating wet deposition, based on the mathematical relationship between the target variables, daily wet

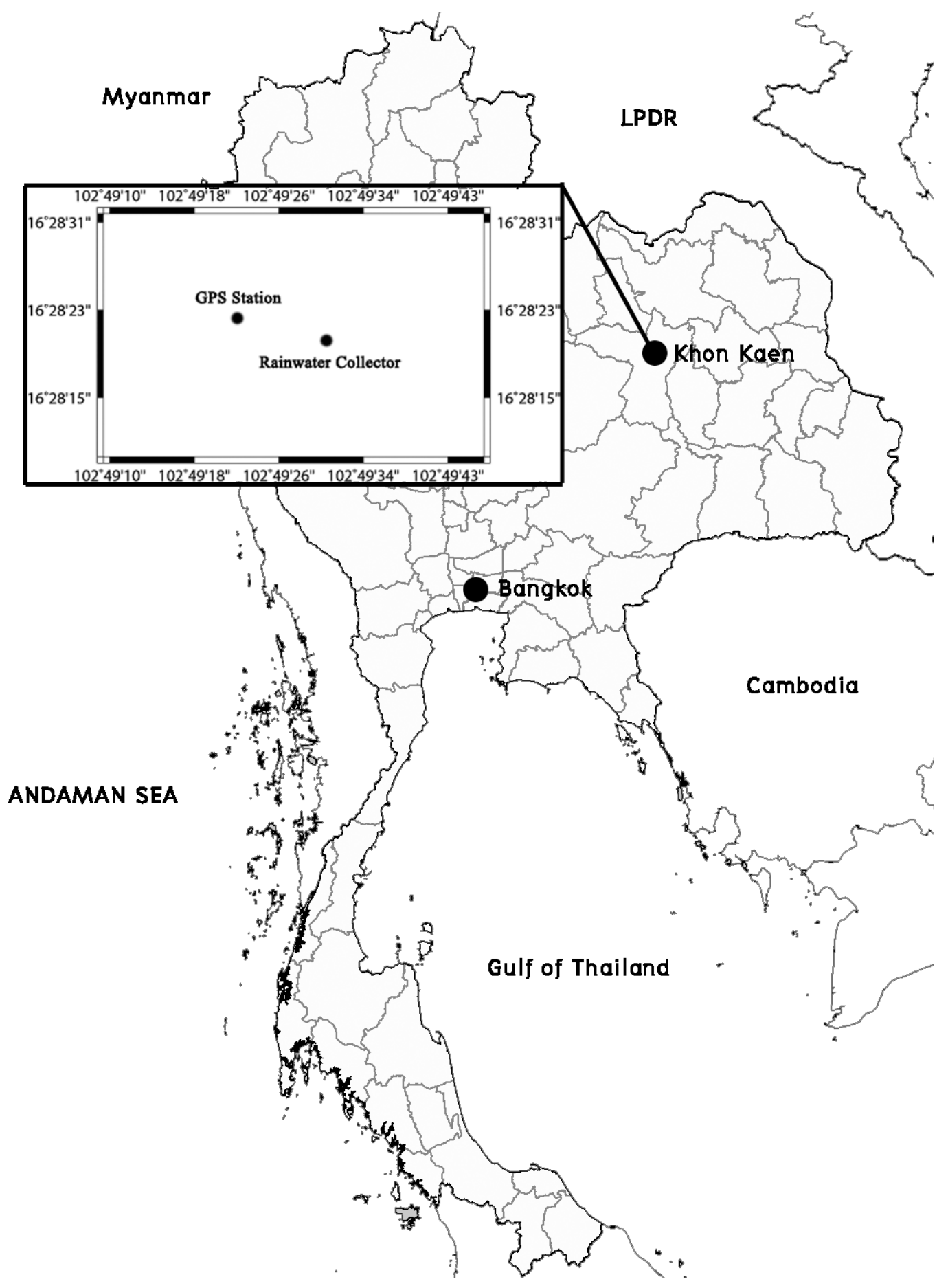

Fig.1 Location of GPS Station and Rainwater Collector 
deposition flux (Section 2.2), the independent variables ZHD and ZWD (Section 2.4), and the meteorological data measured in the study areas (including daily rainfall and daily average wind speed). The data were divided into two groups: 1) $90 \%$ of the data were used as a training data set for regression analysis using COMBI GMDH; and 2) the remaining $10 \%$ for testing the data set in the validation model - using GMDH Shell for Data Science 3.7.1.

GMDH is a data mining computational method. It can create a relatively accurate mathematical model without defining the relationship between the variables. The basic connection between inputs and an output can be expressed as:

$$
y=a_{0}+\sum_{i=1}^{n} a_{i} f_{i}
$$

...where ' $a$ ' are coefficients, ' $n$ ' the number of base functions, and ' $f$ ' the base function. The well-known base function of GMDH is the Kolmogorov-Gabor polynomial:

$$
y=a_{0}+\sum_{i=1}^{m} a_{i} X_{i}+\sum_{i=1}^{m} \sum_{j=1}^{m} a_{i j} X_{i} X_{j}+\sum_{i=1}^{m} \sum_{j=1}^{m} \sum_{k=1}^{m} a_{i j k} X_{i} X_{j} X_{k}
$$

...where ' $x$ ' are the input variables and ' $m$ ' the number of variables. GMDH hereby "selects" the various algorithms (i.e., combinatorial (COMBI), multilayer algorithm, harmonic and fuzzy). GMDH can, moreover, be used in neural networks - i.e., polynomial neural networks (PNN) or GMDH-type neural networks [14]. Despite requiring a longer calculation time and greater processing power, COMBI GMDH is a popular and comparatively accurate regression algorithm for analyzing not more than 25 variables [15]. The current study had only five variables and a low-priced high-performance computer, so we chose to use COMBI GMDH as the main algorithm.

\section{Results and Discussion}

\section{Rainwater Quality}

Eighty-five samples of rainwater were collected. The $\mathrm{pH}$ of the samples ranged from 5.02 to 6.90 (average, 5.62). The respective concentration range of the cations $\mathrm{Ca}^{2+}, \mathrm{Mg}^{2+}, \mathrm{Na}^{+}, \mathrm{K}^{+}$, and $\mathrm{NH}_{4}^{+}$in the rainwater was $3.70-141.68,0.00-108.64,0.00-210.00,0.00-253.96$, and $0.00-495.49 \mu \mathrm{mol} / \mathrm{L}$. The respective concentration range of the anions $\mathrm{SO}_{4}^{2-}, \mathrm{NO}^{3-}, \mathrm{Cl}^{-}, \mathrm{PO}_{4}^{3-}, \mathrm{HCOO}^{-}$, and $\mathrm{CH}_{3} \mathrm{COO}^{-}$was 1.44-84.90, 1.95-252.34, 1.23-186.88, $0.00-14.03,0.00-3.88$, and $0.00-7.39 \mu \mathrm{mol} / \mathrm{L}$. The rank of the average charge most frequently found was $\mathrm{NH}_{4}^{+}>\mathrm{Ca}^{2+}$ $>\mathrm{NO}_{3}{ }^{-}>\mathrm{Cl}^{-}>\mathrm{Na}^{+}>\mathrm{SO}_{4}{ }^{2-}>\mathrm{K}^{+}>\mathrm{Mg}^{2+}>\mathrm{HCO}_{2}{ }^{-}>\mathrm{PO}_{4}{ }^{3-}>$ $\mathrm{CH}_{3} \mathrm{COO}^{-}$(Table 1).

The rainwater in the study area showed acidity, suggesting a source of pollutants, possibly from: a)
Table 1. Rainwater quality.

\begin{tabular}{|c|c|c|c|}
\hline Parameter & Unit & Range & Average \\
\hline $\mathrm{pH}$ & - & $5.02-6.90$ & 5.62 \\
\hline $\mathrm{Ca}^{2+}$ & $\mu \mathrm{mol} / \mathrm{L}$ & $3.70-141.68$ & 30.06 \\
\hline $\mathrm{Mg}^{2+}$ & $\mu \mathrm{mol} / \mathrm{L}$ & $0.00-108.64$ & 6.31 \\
\hline $\mathrm{Na}^{+}$ & $\mu \mathrm{mol} / \mathrm{L}$ & $0.00-210.00$ & 14.17 \\
\hline $\mathrm{K}^{+}$ & $\mu \mathrm{mol} / \mathrm{L}$ & $0.00-253.96$ & 8.24 \\
\hline $\mathrm{NH}_{4}^{+}$ & $\mu \mathrm{mol} / \mathrm{L}$ & $0.00-495.49$ & 46.14 \\
\hline $\mathrm{SO}_{4}{ }^{2-}$ & $\mu \mathrm{mol} / \mathrm{L}$ & $1.44-84.90$ & 9.96 \\
\hline $\mathrm{NO}_{3}{ }^{-}$ & $\mu \mathrm{mol} / \mathrm{L}$ & $1.95-252.34$ & 22.73 \\
\hline $\mathrm{Cl}^{-}$ & $\mu \mathrm{mol} / \mathrm{L}$ & $1.23-186.88$ & 17.61 \\
\hline $\mathrm{PO}_{4}{ }^{3-}$ & $\mu \mathrm{mol} / \mathrm{L}$ & $0.00-14.03$ & 0.62 \\
\hline $\mathrm{HCOO}^{-}$ & $\mu \mathrm{mol} / \mathrm{L}$ & $0.00-3.88$ & 0.68 \\
\hline $\mathrm{CH}_{3} \mathrm{COO}^{-}$ & $\mu \mathrm{mol} / \mathrm{L}$ & $0.00-7.39$ & 0.21 \\
\hline
\end{tabular}

natural sources such as $\mathrm{CO}_{2}$ from respiration or $\mathrm{NO}$ from lightning strikes, which were dissolved in the rain, creating acid precipitation; and b) man-made sources from vehicle exhaust or waste incineration releasing $\mathrm{NO}, \mathrm{NO}_{3}$, and/or $\mathrm{SO}_{2}$, corresponding to the number of $\mathrm{NO}_{3}^{-}$and $\mathrm{SO}_{4}^{2-}$ charges found in the samples [5]. This human activity is primarily responsible for increasing acidifying atmospheric pollutants, which is causing acid rain. Although rainwater in the study area was acidic, no serious acid rain (i.e., a $\mathrm{pH}<5$ ) was observed during the research (Fig. 2).

\section{Wet Deposition}

The respective range of wet deposition of $\mathrm{Ca}^{2+}, \mathrm{Mg}^{2+}$, $\mathrm{K}^{+}, \mathrm{NH}_{4}^{+}$, and $\mathrm{Na}^{+}$was $0.63-173.52,0.00-69.98,0.00-$ $14.07,0.00-123.50$, and 0.00-67.28 $\mu \mathrm{mol} / \mathrm{m}^{2}$-day, and of $\mathrm{CH}_{3} \mathrm{COO}^{-}, \mathrm{HCOO}^{-}, \mathrm{Cl}^{-}, \mathrm{SO}_{4}{ }^{2-}, \mathrm{NO}_{3}^{-}$, and $\mathrm{PO}_{4}^{3-}$ was 0.00-0.39, 0.00-2.25, 0.19-31.72, 0.34-93.73, 0.14-62.71, and $0.00-17.16 \mu \mathrm{mol} / \mathrm{m}^{2}$-day (Table 2). The respective daily maximum, minimum, and average wet depositions were 431.41, 3.10, and $68.60 \mu \mathrm{mol} / \mathrm{m}^{2}$-day (Fig. 3). $\mathrm{Ca}^{2+}$ had the highest annual wet deposition by charge at 1,933.59 $\mu \mathrm{mol} / \mathrm{m}^{2}$-year, followed by $\mathrm{NH}_{4}^{+}, \mathrm{SO}_{4}^{2-}, \mathrm{NO}_{3}^{-}, \mathrm{Mg}^{2+}, \mathrm{Cl}^{-}$, $\mathrm{Na}^{+}, \mathrm{K}^{+}, \mathrm{PO}_{4}^{3-}, \mathrm{HCOO}^{-}$, and $\mathrm{CH}_{3} \mathrm{COO}^{-}$at $908.93,731.92$, $416.04,284.25,265.14,221.05,88.24,73.42,15.81$, and $1.16 \mu \mathrm{mol} / \mathrm{m}^{2}$-year, respectively.

The analysis of annual wet deposition showed that the area had particles of limestone (i.e., $\mathrm{CaCO}_{3}$ and $\mathrm{CaO}$ ) in the atmosphere: these particles generated $\mathrm{Ca}^{2+}$ with the highest annual wet deposition. Alkaline dust in the atmosphere was, however, beneficial as it helped to reduce $\mathrm{H}_{2} \mathrm{SO}_{4}$ (the reaction of $\mathrm{H}_{2} \mathrm{O}$ with $\mathrm{SO}_{2}$ ) [16]. The most important discovery was finding high $\mathrm{NH}_{4}^{+}$in the wet deposition. If $\mathrm{NH}_{4}^{+}$falls to the ground, microbes convert it to $\mathrm{NO}_{3}{ }^{-}$with the nitrification process, resulting in a higher deposition of $\mathrm{NO}_{3}^{-}$and a greater possibility of $\mathrm{HNO}_{3}$. 


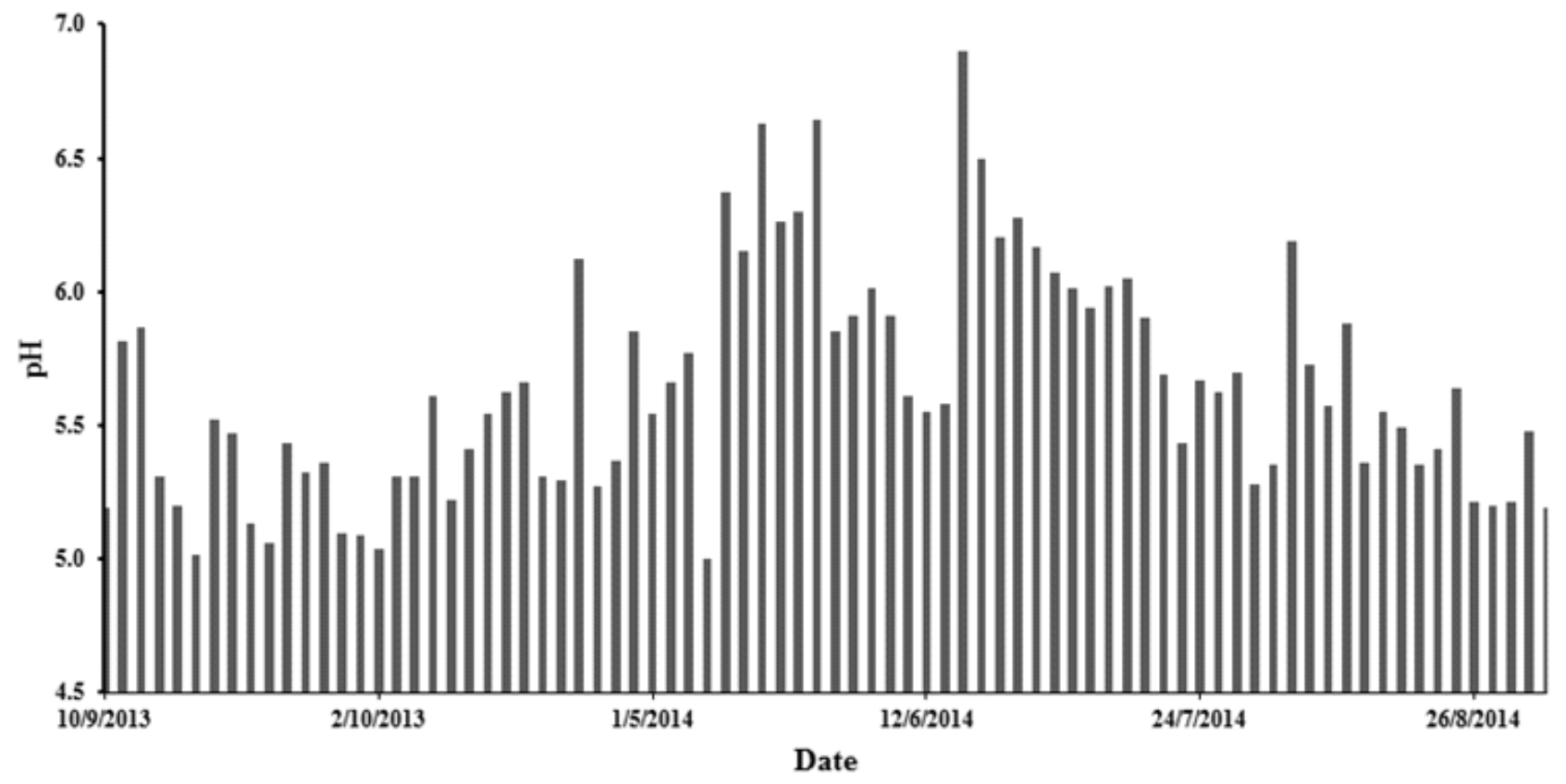

Fig. 2. pH of samples.

Since $\mathrm{NO}_{3}^{-}$and $\mathrm{NH}_{4}^{+}$are key factors in eutrophication, environmental monitoring is necessary to balance $\mathrm{NH}_{4}^{+}$ from fertilizer with residual $\mathrm{NH}_{4}^{+}$in the soil, water, and atmosphere [16]. Importantly, the detection of high $\mathrm{Ca}^{2+}$ and $\mathrm{NH}_{4}^{+}$was found in the agricultural zones of Thailand (i.e., Nakorn Pathom) [17]. Annual wet deposition of $\mathrm{SO}_{4}^{2-}$ and $\mathrm{NO}_{3}{ }^{-}$were high compared to the other charges; perhaps because of combustion, motor vehicle exhaust, and incineration at nearby factories.

\section{GPS-Derived Atmospheric Propagation Delay}

Based on the estimated value of GPS-derived atmospheric propagation delay of both parts, ZHD and

Table 2. Wet deposition ( $\mu \mathrm{mol} / \mathrm{m}^{2}$-day).

\begin{tabular}{|c|c|c|}
\hline Ion & Range & Average \\
\hline $\mathrm{Ca}^{2+}$ & $0.63-173.52$ & 26.86 \\
\hline $\mathrm{Mg}^{2+}$ & $0.00-69.98$ & 3.95 \\
\hline $\mathrm{Na}^{+}$ & $0.00-67.28$ & 3.07 \\
\hline $\mathrm{K}^{+}$ & $0.00-14.07$ & 1.23 \\
\hline $\mathrm{NH}_{4}^{+}$ & $0.00-123.50$ & 12.62 \\
\hline $\mathrm{SO}_{4}{ }^{2-}$ & $0.34-93.73$ & 10.17 \\
\hline $\mathrm{NO}_{3}{ }^{-}$ & $0.14-62.71$ & 5.78 \\
\hline $\mathrm{Cl}^{-}$ & $0.19-31.72$ & 3.68 \\
\hline $\mathrm{PO}_{4}{ }^{3-}$ & $0.00-17.16$ & 1.02 \\
\hline $\mathrm{HCOO}^{-}$ & $0.00-2.25$ & 0.22 \\
\hline $\mathrm{CH}_{3} \mathrm{COO}^{-}$ & $0.00-0.39$ & 0.02 \\
\hline
\end{tabular}

ZWD, the average ZHD was 2,247.29 $\mathrm{mm}$. The highest value was $2,274.01 \mathrm{~mm}$ on 18 January 2014, and the lowest 2,227.54 $\mathrm{mm}$ on 12 June 2014. The average ZWD was $294.48 \mathrm{~mm}$. The highest value was $417.16 \mathrm{~mm}$ on 19 September 2013 and the lowest was $71.00 \mathrm{~mm}$ on 23 January 2014 (Fig. 4). In December 2013 and May 2014 ZHD and ZWD values could not be estimated because of recorder malfunction.

Comparing ZHD to ZWD over the same period, ZHD showed an inverse relationship with ZWD; ZHD increased in the dry season (November-April) and decreased during the rainy season (May-October). Conversely, ZWD decreased in the dry season and increased during the rainy season. This result agrees with that of Bevis et al., who demonstrated that ZWD was directly related to the total column water vapor, known as precipitable water vapor (PWV). When the atmosphere contained large quantities of water vapor during the rainy season, ZWD was high. Satomura et al. found that PWV in Thailand always increases during the rainy season [18]. Thus, when PWV was high in the rainy season, ZWD was also high due to the change of PWV.

\section{Wet Deposition Model}

Our current research covers regression by applying COMBI GMDH to analyze the relationship between rainwater quality, GPS-derived atmospheric propagation delay, and meteorological data. The target variable was daily wet deposition and the independent variables were ZHD, ZWD, daily rainfall, and daily average wind speed. Eighty-five samples were collected in order to analyze wet deposition as input data. GPS data to estimate ZHD and ZWD was only recorded on 72 rainy days, so analysis of the regression used only 72 sets of data. The data were 


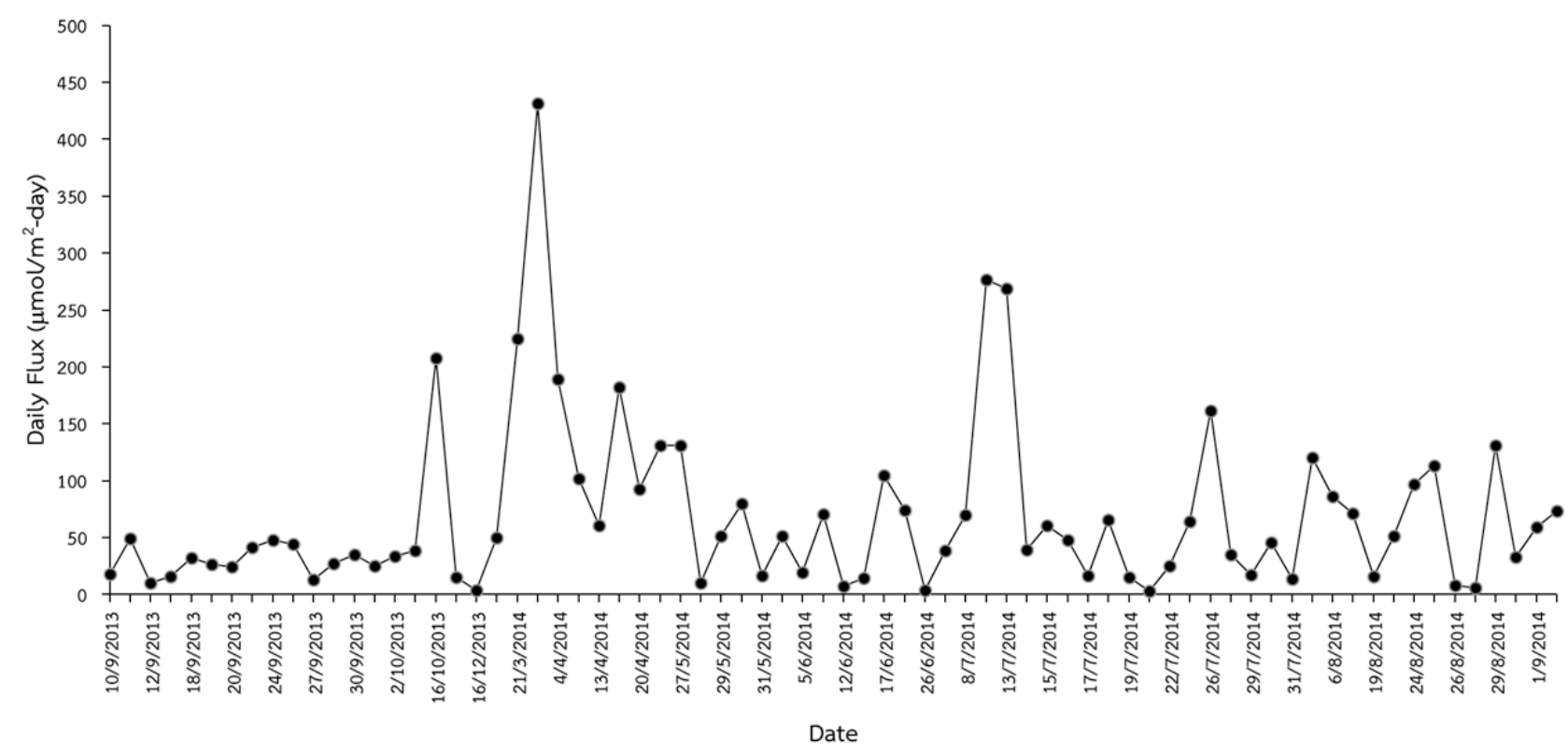

Fig. 3. Daily wet deposition.

divided into two groups: 65 training data and seven testing data (as described in section 2.5). The regression analysis was performed by the mathematical relation in the polynomial:

$$
\begin{gathered}
F=42.442-75.653 * Z W D * Z H D^{-1}+0.133 * \\
* Z W D * R+3.384 e^{6} * R * Z W D^{-2} \\
-12.024 * R^{-1} W^{-2}-72.886 R-1.0976 R^{-1}
\end{gathered}
$$

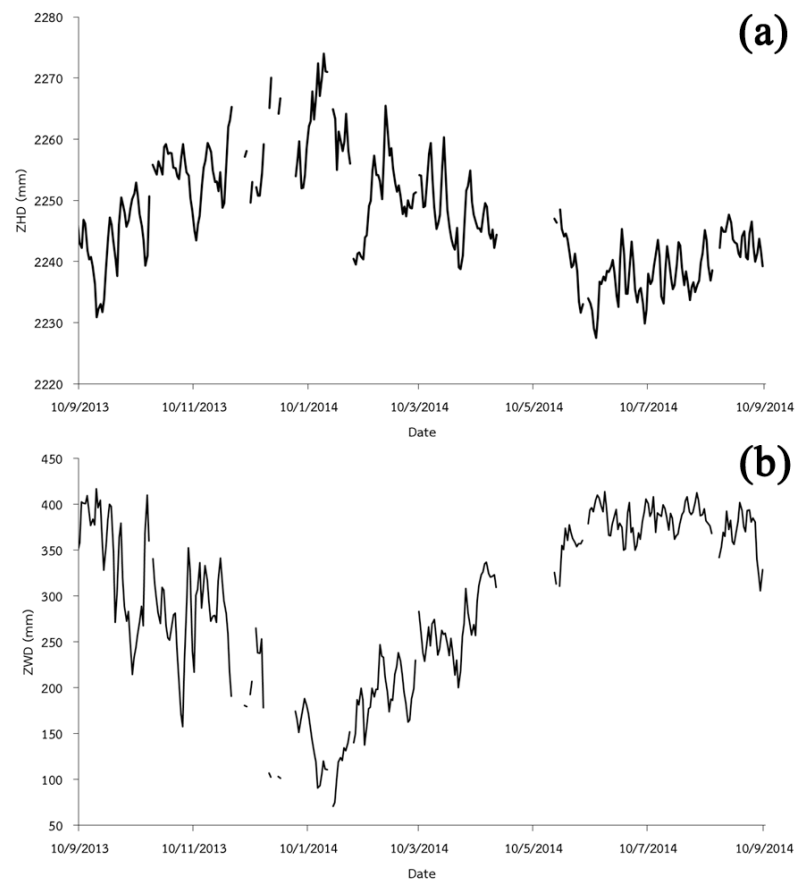

Fig. 4. (a) Zenith hydrostatic delay and (b) zenith wet delay. ...where ' $\mathrm{F}$ ' is daily wet deposition ( $\mu \mathrm{mol} / \mathrm{m}^{2}$-day), ZHD the zenith hydrostatic delay ( $\mathrm{mm}), \mathrm{ZWD}$ the zenith wet delay $(\mathrm{mm})$, ' $\mathrm{R}$ ' the daily rainfall $(\mathrm{mm})$, and ' $\mathrm{W}$ ' daily wind speed $(\mathrm{m} / \mathrm{s})$. This model had a coefficient of determination $\left(R^{2}\right)$ at 0.70 , with the correlation coefficient at 0.84 . MAE was $30.20 \mu \mathrm{mol} / \mathrm{m}^{2}$-day and RMSE was $40.94 \mu \mathrm{mol} / \mathrm{m}^{2}$-day. Testing the model determined $R^{2}$ at 0.95 , with the correlation coefficient at 0.98 . MAE was $12.14 \mu \mathrm{mol} / \mathrm{m}^{2}$-day and RMSE was $15.35 \mu \mathrm{mol} / \mathrm{m}^{2}$-day (Fig. 5).

The $R^{2}$ of the mathematical model - applied ZHD, ZWD, daily rainfall, and daily average wind speed for estimating daily wet deposition from the regression analysis was done using the COMBI GMDH. The process of creating and testing the model was successful; there was a high correlation coefficient, suggesting a close relationship between the four independent variables and daily wet deposition. This might be because the pollutants that cause contamination in rainwater (i.e., gases, sand, dust, aerosol, and ash) were the reasons for the GPSderived delay. The microwave signal - broadcast from GPS satellites - might be absorbed by atmospheric gases (e.g., water vapor, ozone, carbon monoxide, nitrous oxide, chlorine monoxide, oxygen, and ammonia). As a consequence, the ZHD value was related to the refraction index $(\mathrm{N})$ and changed due to the quantities of gas in the atmosphere that caused the acid charges (i.e., $\mathrm{N}_{2}$, $\mathrm{NO}_{2}-$ caused $\mathrm{NO}_{3}^{-}$, and $\mathrm{H}_{2} \mathrm{~S}$ - and $\mathrm{SO}_{2}$-caused $\mathrm{SO}_{4}{ }^{2-}$ ). Daily wet deposition was then calculated from the wet deposition flux (F) as directly related to rainfall (R) (Equation 1). ZWD was also related to wet deposition, as ZWD is widely accepted for estimating PWV - the parameter of water vapor in the atmosphere associated with rainfall (R) [19]. Wind speed data (W) is possibly related to rain, since wind is a significant variable for moistness [20], and a factor in moving the dust from the ground to the atmosphere [21]. 


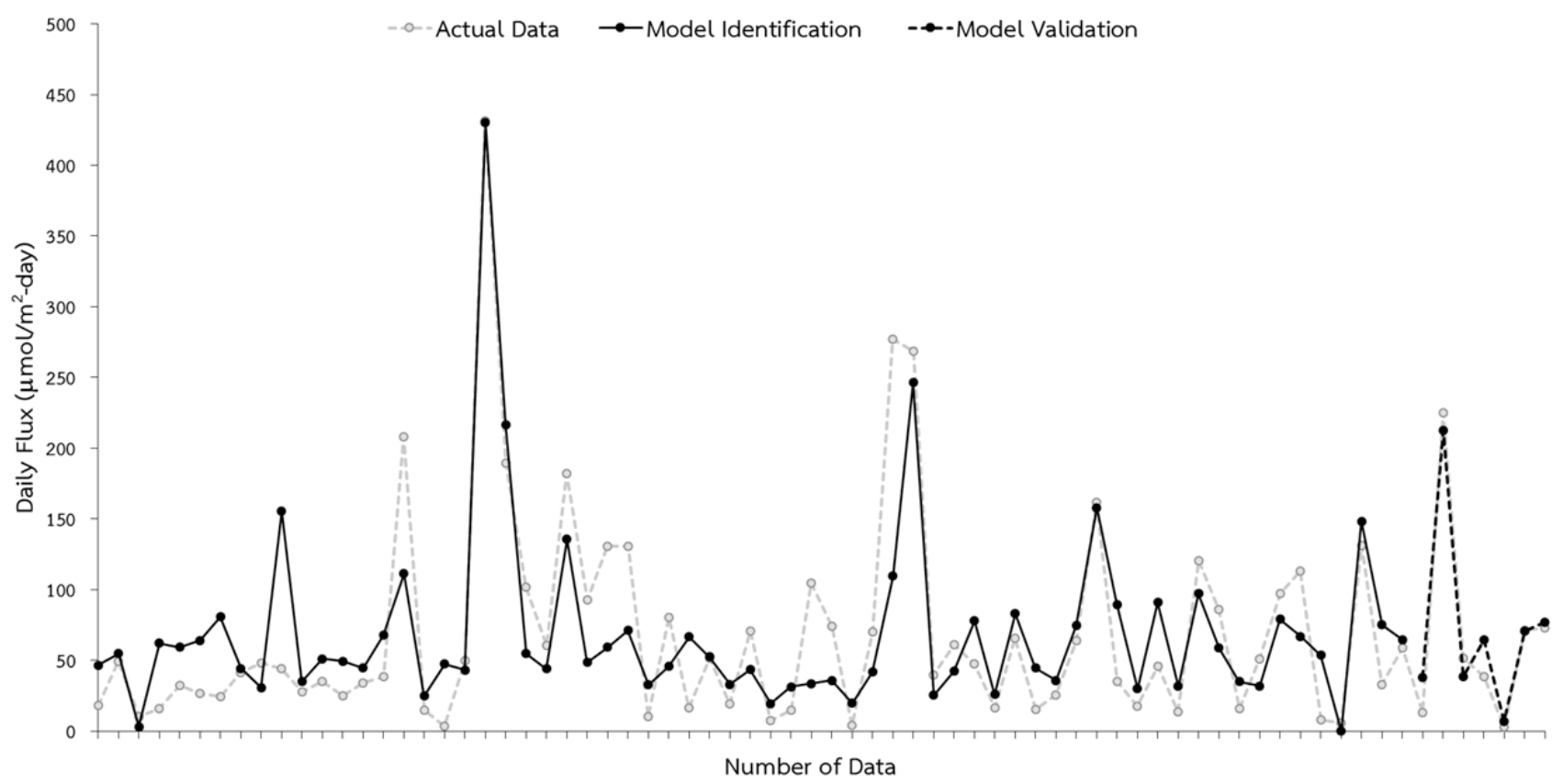

Fig. 5. Plot of daily wet deposition model.

Results of regression model testing indicated the possibility of implementing the GPS-derived atmospheric propagation delay and meteorology data to estimate daily wet deposition as the $R^{2}$ was acceptable and the model had a high-value correlation coefficient. The model also had a low MAE value in the creating and validation process; thus, it could be used to estimate rainwater quality in the study area quickly and efficiently. In future, if the input data (i.e., rainwater quality, meteorological data, and GPS data) were collected in high quantity and continuously, then the model might be even more accurate as the COMBI GMDH will learn and create the best model fit. The model will then be able to adjust to suit the situation and provide results closer to the actual recorded measurements.

\section{Conclusions}

Based on collection and analysis of rainwater at Khon Kaen University over one year, the $\mathrm{pH}$ of 85 samples varied between 5.02 and 6.90 (with none $<5.0$ ). There was, therefore, no risk of hazardous acid rain found. $\mathrm{NH}_{4}^{+}$ was the ion with the highest concentration $(46.14 \mu \mathrm{mol} / \mathrm{L})$, followed in lesser amounts by $\mathrm{Ca}^{2+}, \mathrm{NO}_{3}^{-}, \mathrm{Cl}^{-}, \mathrm{Na}^{+}, \mathrm{SO}_{4}^{2-}$, $\mathrm{K}^{+}, \mathrm{Mg}^{2+}, \mathrm{HCOO}^{-}, \mathrm{PO}_{4}^{3-}$, and $\mathrm{CH}_{3} \mathrm{COO}^{-}$.

Daily wet deposition varied between 3.10 and $431.41 \mu \mathrm{mol} / \mathrm{m}^{2}$-day (average $68.60 \mu \mathrm{mol} / \mathrm{m}^{2}$-day). The charge with the highest yearly deposition was $\mathrm{Ca}^{2+}$, followed by $\mathrm{NH}_{4}^{+}, \mathrm{SO}_{4}^{2-}, \mathrm{NO}_{3}^{-}, \mathrm{Mg}^{2+}, \mathrm{Cl}^{-}, \mathrm{Na}^{+}, \mathrm{K}^{+}, \mathrm{PO}_{4}^{3-}$, $\mathrm{HCOO}^{-}$, and $\mathrm{CH}_{3} \mathrm{COO}^{-}$, in descending order.

Estimating the GPS-derived atmospheric propagation delay in the Khon Kaen University area with GAMIT yielded a ZHD value between 2,274.01 and 2,227.54 mm (average, 2,247.29 mm), and a ZWD between 71.00 and $417.16 \mathrm{~mm}$ (average, $294.48 \mathrm{~mm}$ ). ZHD was inversely related to ZWD: ZHD increased in the dry season and decreased in the rainy season.

The COMBI GMDH regression analysis between daily wet deposition and the independent variables (viz., ZHD, ZWD, daily rainfall, and daily average wind speed) had an $R^{2}$ of 0.70 , while the correlation coefficient was 0.84 . The respective MAE and RMSE were 30.20 and $40.94 \mu \mathrm{mol} / \mathrm{m}^{2}$-day. The $R^{2}$ of the test data set was 0.95 , with a correlation coefficient of 0.98 , with a MAE of $12.14 \mu \mathrm{mol} / \mathrm{m}^{2}$-day, and a RMSE of $15.35 \mu \mathrm{mol} / \mathrm{m}^{2}$-day. Using meteorological conditions, atmospheric gases, and other pollutants causing contamination in the rainwater (sand, dust, and aerosols) that cause GPS delay, the COMBI GMDH model can estimate preliminary rainwater quality as quickly and as efficiently as the laboratory. This would be beneficial for rainwater quality observers in areas conducting acid rain hazard prevention measures.

\section{Acknowledgements}

We thank the Research Fund of Khon Kaen University, Thailand, and the Higher Education Research Promotion, National Research University Project of Thailand, Office of the Higher Education Commission for supporting this research, plus Mr. Saman Prakarnrat for Meteorological data and Dr. Akraphon Janon and Mr. Bryan Roderick Hamman for assistance with the English-language presentation of the manuscript.

\section{References}

1. NOYES P.D., MCELWEE M.K., MILLER H.D., CLARK B.W., VAN TIEM L.A., WALCOTT K.C., ERWIN 
K.N., LEVIN E.D. The toxicology of climate change: Environmental contaminants in a warming world, Environ. Int., 35, 971, 2009.

2. SUDALMA S., PURWANTO P., SANTOSO L.W. The Effect of $\mathrm{SO}_{2}$ and $\mathrm{NO}_{2}$ from Transportation and Stationary Emissions Sources to $\mathrm{SO}_{4}^{2-}$ and $\mathrm{NO}_{3}^{-}$in Rain Water in Semarang, P. Environ. Sci., 23, 247, 2015.

3. SINGH A., AGRAWAL M. Acid rain and its ecological consequences, J Environ Biol., 29, 15, 2008.

4. SCHNEIDER T., O'GORMAN P.A., LEVINE X.J. Water Vapor and The Dynamics of Climate Changes, Rev. Geophys., 48, 1, 2010.

5. WANG X., LIU Z., NIU L., FU B. Long-term effects of simulated acid rain stress on a staple forest plant, Pinus massoniana Lamb: a proteomic analysis, Trees, 27, 297, 2012.

6. LI J., JIA C., LU Y., TANG S., SHIM H. Multivariate analysis of heavy metal leaching from urban soils following simulated acid rain, Microchem. J., 122, 89, 2015.

7. ERKAL A., D'AYALA D., SEQUEIRA L. Assessment of wind-driven rain impact, related surface erosion and surface strength reduction of historic building materials, Build. Environ., 57, 336, 2012.

8. CAHOON L.B. Coal Use as a Cause of Water Quality Impairment; in S. Ahuja., eds, Food, Energy, and Water, Elsevier, Boston, 261, 2015.

9. PRIHATIN J., COREBIMAA.D., ARIFFIN GOFUR A. The Effect of Exposure of Mulberry to Acid Rain on the Defects Cocoon of Bombyxmori L, P. Environ. Sci., 23, 186, 2015.

10. RICE E.W. American Public Health Association, Eds., Standard methods for the examination of water and wastewater, $22^{\text {th }}$ Edn., American Public Health Association, Washington, 2012.

11. HERRING T.A., KING R.W., MCKLUSKY S.C., Gamit Reference Manual GPS Analysis at MIT, Massachusetts Institute of Technology, Boston, 2010.
12. BENNITT G.V., JUPP A. Operational Assimilation of GPS Zenith Total Delay Observations into the Met Office Numerical Weather Prediction Models, Mon. Wea. Rev., 140, 2706, 2012.

13. BOSY J., ROHM W., BORKOWSKI A., KROSZCZYNSKI K., FIGURSKI M. Integration and verification of meteorological observations and NWP model data for the local GNSS tomography, Atmos. Res., 96, 522, 2010.

14. DORN M., BRAGA A.L.S., LLANOS C.H., COELHO L.S. A GMDH polynomial neural network-based method to predict approximate three-dimensional structures of polypeptides, Expert. Syst. Appl., 39, 12268, 2012.

15. ROEBUCK K. Data Mining: High-impact Strategies What You Need to Know: Definitions, Adoptions, Impact, Benefits, Maturity, Vendors, Emereo Publishing, Brisbane, 2012.

16. PARK C.C. Acid Rain (Routledge Revivals): Rhetoric and Reality, Routledge, 2013.

17. PANYAKAPO M., ONCHANG R. A four-year investigation on wet deposition in western Thailand, J. Environ. Sci., 20, 441, 2008.

18. SATOMURA M. et al., On the precipitable water vapor obtained by using GPS observations in Thailand (20012006), Geosci. R. Shizuoka U., 1, 1, 2010.

19. SHI JUNBO, XU CHAOQIAN, GUO JIMING, GAO YANG, Real-Time GPS Precise Point Positioning-Based Precipitable Water Vapor Estimation for Rainfall Monitoring and Forecasting, IEEE. T. Geosci. Remote, 53, 3452, 2015.

20. BLOCKEN B., CARMELIET J. Overview of three state-ofthe-art wind-driven rain assessment models and comparison based on model theory, Build. Environ., 45, 691, 2010.

21. GERIVANI H., LASHKARIPOUR G.R., GHAFOORI M. The Source of Dust Storm in Iran: A case study based on geological information and rainfall data, Carpath. J. Earth. Env., 6, 297, 2011. 